\title{
The Development of Fantasy Make Up Instructional Dictate for Students in the Cosmetology Study Program of the Faculty of Engineering, State University of Medan
}

\author{
Marnala Tobing ${ }^{1}$, Irmiah Nurul Rangkuti ${ }^{2}$, Dian Maya Sari $^{3}$, Desy Afyanty Lubis $^{4}$ \\ FT Universitas Negeri Medan ${ }^{1,2,3,4}$ \\ missirmiahnurul@gmail.com
}

\begin{abstract}
This study aimed to: (1) produce instructional dictate which decent to be used, easy to learn by students and be used for individual learning. (2) to discover the effectiveness of instructional dictate media for character make up that developed on fantasy make up. This type of research is development of research that use the product model Borg and Gall combined by a learning development model of Dick and Carey. The collected data were analyzed by qualitative descriptive analysis technique. The hypothesis results proves that: (1) the instructional dictate is worthy to use for fantasy make up on cosmetology course State University of Medan, (2) there is significantly difference between student learning outcomes who applied by instructional dictate media for fantasy make up and student learning outcomes who not applied. This is shown by data result processing and concluded that use of instructional dictate media is more effective to improving the competency and knowledge of students in learning fantasy makeup than without applied.
\end{abstract}

Keywords: Development of instructional dictate, fantasy make up

\section{Introduction}

The Unimed Faculty of Engineering (FT) Cosmetology Study Program, which was opened since the 2007/2008 year, is one of the efforts to meet the needs of the community for teachers who are professional and skilled in the field of makeup in the future. Improving the quality of learning in higher education, especially in educational personnel education institutions still and must be continuously improved.

Based on the constraints that exist in the cosmetology education study program, the researchers feel that the development of Instructional in the form of learning dictate is the most urgent problem, because considering the difficulty of getting learning dictate that suits the needs of students and lecturers in fantasy makeup while supporting facilities for applying is well available in Unimed cosmetology education study programs. With the existence of good learning media the other obstacles encountered by the majority can be overcome such as the lack of teaching materials and learning support books because learning media can be an alternative as a learning media. Through 
good learning media, the lecturers' time to explain the learning material will be more concise, and students can immediately practice the learning material presented by the lecturers so that students and lecturers need a media that can assist in the learning process of fantasy make up

The lack of achievement of competency standards in practical courses causes less growth in student motivation and creativity in the learning process, in this case especially in the learning process of fantasy makeup courses. In fact, fantasy makeup courses are knowledge that must be understood and applied, not just in the form of memorization. Fantasy makeup material itself is an ongoing material from one unit and complex. The theories in the book or module are able to become a means of forming creativity and independence of students, because students do not see directly the technique of fantasy makeup applications in stages. In addition, the absorption of students is certainly not the same for everyone, you will be very lacking in understanding the techniques or fantasy makeup applications intended, because there are examples with colors. This results in students not being able to imagine to be able to foster maximum creativity. Instructional dictate will also enable learners to provide feedback, feedback and also encourage learners to practice correctly.

Seeing this reality, it is necessary to develop learning instructional dictate in fantasy makeup courses. The use of information technology in the form of instructional dictate that are equipped with attractive animated drawing features can make learning take place interesting and create a learning process that is not monotonous and boring, and easy to understand. In addition, it can also help students capture the material to be delivered, and of course it can be applied directly without having to wait for lectures delivered or supervised by lecturers. Thus, students can learn independently and can be creative according to their talents and interests.

Instructional dictate is a medium that is suitable for various learning such as classes, small groups, even for independent learning. From that, instructional dictate with a duration of only a few minutes can provide more flexibility for lecturers and can direct learning directly to the needs of students. In addition, according to Smaldino [1], learning with multi-voice instructional dictate can be aimed at various types of students.

The use of learning instructional dictate will add a broader dimension to students and can motivate learning and broaden the horizons of students and lecturers not only as users or users of instructional dictate but guided as designers so it is necessary to know practical knowledge on how to make learning instructional dictate and recognize various instructional dictate formats and skills use it. Things that cannot be ignored are must understand visual principles and how to design visual messages properly and effectively.

\section{Research Method}

This research was conducted in the Cosmetology Study Program of the Family Welfare Education Department (PKK) of the Faculty of Engineering, Medan State University, for the fourth semester / even students of the Beauty Management Program 2016/2017 academic year. In this research and development the model that will be developed refers to the Research and Development (R \& D) of the Borg \& Gall model which has the aim of developing and validating the product by planning learning in the development of Dick \& Carey's learning instructional dictate. The development model is a series of procedures in order to produce fantasy makeup learning media for 
students from field state cosmetology education study programs. The development model used is in the form of media fantasy makeup learning instructional dictate designed by explaining the stages of dressing old characters with the theme of witches in stages (step by step). The stages of development adopt the stages of development of Borg \& Gall models [2] as follows:

1. Conduct preliminary research which includes:

a. Identify learning needs and determine competency standards in the course

b. Conduct learning analysis

c. Identify the characteristics and initial behavior of students

d. Write basic competencies and indicators

e. Write a benchmark reference test

f. Develop learning strategies that are realized in the form of syllabus and learning units

g. Develop learning materials

h. Design formative evaluations

2. Design learning instructional dictate:

a. Re-identify material and summarize it

b. Making a script / storyboard

3. Collection of materials which include:

a. Audio recording and collection

b. Capturing and logging material from shooting on the Adobe Premiere program in AVI format

c. Editing stage (image, text, sound effect, music instrument, animation)

d. rendering using the mpeg extension (VCD format)

e. Develop and create learning instructional dictate

f. Burning learning media into VCDs

4. Review and test the product:

The product review and trial phase is carried out to material experts, learning media experts, instructional dictate and graphic design experts. After going through the revision stage then proceed to students with three stages, namely individual trials, small group trials and field trials so that the resulting learning instructional dictate that is appropriate to use in accordance with the characteristics of the field of study and students as users. Through a series of expert trials and trials to students finally the final product of learning instructional dictate is produced by incorporating suggestions and revisions from content / material experts, learning media experts, instructional dictate and graphic design experts, and students.

5. Test the effectiveness of the product

Product effectiveness testing is done by analyzing student learning outcomes in fantasy makeup courses.

Data analysis to test the first hypothesis concerning the feasibility of media fantasy makeup learning instructional dictate used non-test techniques used to collect product data, by validating the design of instructional dictate which includes the process of activities to assess the feasibility of media before being used as a learning media. Evaluation was carried out by validators who had been given trust in validating the design of learning instructional dictate who were experts in the fields of media, science, and technology, and several student groups. All data collected was analyzed using statistical techniques. 
Qualitative data in the form of statements that are very poor, bad, moderate, good and very good are converted into quantitative data with a value scale of 1 to 5 .

The population in this study were the students of cosmetology education study program at Medan State University who knew the 2016/2017 academic number of 58 people divided into 2 classes namely class A as the control class and class B as the experimental class.

The research hypotheses that will be tested are: (1) Media suitable fantasy makeup learning instructional dictate are used as a medium for student learning, (2) Learning instructional dictate are more effective for improving student learning outcomes in students of the Medan State University education study program compared to students who taught using conventional media.

\section{Results and Discussion}

The results of the study by material experts, learning design experts, and learning instructional dictate experts and graphic design in each aspect of the overall assessment were determined by the average score in each category. The results of the assessment were then analyzed to determine the media feasibility of fantasy makeup learning instructional dictate that had been developed. The average percentage from the assessment of material experts, learning design experts and graphic and graphic design experts are described as follows:

Data Analysis of Material Evaluation Results

Table 1. shows the responses of material experts to the instructional dictate learning media included in the

\begin{tabular}{llll}
\multicolumn{4}{c}{ criteria of "very good" } \\
\hline No. & Category & Percentage & Criteria \\
\hline 1. & $\begin{array}{l}\text { Aspects of } \\
\text { Feasibility of Fill }\end{array}$ & $90.00 \%$ & Very Good \\
2. & $\begin{array}{l}\text { Presentation } \\
\text { Aspects }\end{array}$ & $95.00 \%$ & Very Good \\
3. & Language aspect & $90.00 \%$ & \\
4. & Integrity Aspects & $100 \%$ & Very Good \\
Average Percentage & $93.75 \%$ & Very Good \\
\hline
\end{tabular}

Table 2. shows the response of learning design experts to the instructional dictate learning media included in the criteria of "good"

\begin{tabular}{lllll}
\hline No. & Category & & Percentage & Criteria \\
\hline 1. & Aspects & of & $87.50 \% \%$ & Very \\
& Feasibility Fill & & & Good \\
2. & $\begin{array}{l}\text { Presentation } \\
\text { Aspects }\end{array}$ & $80.00 \%$ & Good \\
& $\begin{array}{l}\text { Information } \\
\text { Design Quality }\end{array}$ & & \\
\hline
\end{tabular}




\begin{tabular}{|c|c|c|c|}
\hline No. & Category & Percentage & Criteria \\
\hline 3. & $\begin{array}{l}\text { Aspect of } \\
\text { Presenting } \\
\text { Interaction Quality }\end{array}$ & $70.00 \%$ & Good \\
\hline 4. & Integrity Aspect & $82.85 \%$ & $\begin{array}{l}\text { Very } \\
\text { Good }\end{array}$ \\
\hline \multicolumn{2}{|c|}{ Average Percentage } & $80.08 \%$ & Good \\
\hline
\end{tabular}

Data Analysis of Media Instructional dictates Expert Evaluation Results and Graphic Design

Table 3 shows the response of learning instructional dictate experts to the instructional dictate learning media included in the criteria of "very good"

\begin{tabular}{llll}
\hline No. & Category & Percentage & Criteria \\
\hline 1. & Programming & $88.33 \%$ & Very \\
& Aspects & & Good \\
2. & Technical / display & $91.66 \%$ & Very \\
& $\begin{array}{l}\text { aspects } \\
\text { Average Percentage }\end{array}$ & $89.99 \%$ & Good \\
& & Very \\
& & Good \\
\hline
\end{tabular}

Table 4 shows the student responses to individual tests of learning instructional dictate included in the criteria of "very good"

\begin{tabular}{|c|c|c|c|}
\hline No. & Category & Percentage & Criteria \\
\hline 1. & $\begin{array}{l}\text { Aspects } \\
\text { Learning Materia } \\
\text { Quality }\end{array}$ & $91.66 \%$ & $\begin{array}{l}\text { Very } \\
\text { Good }\end{array}$ \\
\hline 2. & $\begin{array}{l}\text { Technical } \\
\text { display aspects }\end{array}$ & $84.99 \%$ & Very good \\
\hline \multicolumn{2}{|c|}{ Average Percentage } & $88.32 \%$ & $\begin{array}{l}\text { Very } \\
\text { Good }\end{array}$ \\
\hline
\end{tabular}

Table 5 shows the student responses to the small group test of learning instructional dictate included in the

\begin{tabular}{|c|c|c|c|}
\hline No. & Category & Percentage & Criteria \\
\hline 1. & $\begin{array}{l}\text { Aspects of } \\
\text { Learning } \\
\text { Quality }\end{array}$ & $89.16 \%$ & $\begin{array}{l}\text { Very } \\
\text { Good }\end{array}$ \\
\hline 2. & $\begin{array}{l}\text { Technical / display } \\
\text { aspects }\end{array}$ & $86.10 \%$ & $\begin{array}{l}\text { Very } \\
\text { Good }\end{array}$ \\
\hline \multicolumn{2}{|c|}{ Average Percentage } & $87.63 \%$ & $\begin{array}{l}\text { Very } \\
\text { Good }\end{array}$ \\
\hline
\end{tabular}


Table 6 shows students' responses to the small group test of learning instructional dictate included in the

\begin{tabular}{|c|c|c|c|}
\hline No. & Category & Percentage & Criteria \\
\hline 1. & $\begin{array}{l}\text { Aspects of } \\
\text { Learning Material } \\
\text { Quality }\end{array}$ & $97.48 \%$ & $\begin{array}{l}\text { Very } \\
\text { Good }\end{array}$ \\
\hline 2. & $\begin{array}{lr}\text { Technical } & / \\
\text { display } & \text { aspects } \\
98.76 \% & \text { Very } \\
\text { Good } & \end{array}$ & $98.76 \%$ & $\begin{array}{l}\text { Very } \\
\text { Good }\end{array}$ \\
\hline Average & Percentage & $98.30 \%$ & $\begin{array}{l}\text { Very } \\
\text { Good }\end{array}$ \\
\hline
\end{tabular}

Hypothesis I testing is done by sudden normality test to look for normality of the sample under study. The normality test uses the Liliefors test. After the discussion, the experimental class obtained a value of $L_{-}$(count) $=0.136$, while Ltable at the level of $a=0.05$ and $n=29$ was 0.161 . This shows $\mathrm{L}_{-}$(count) $<\mathrm{L}_{\text {( }}$ (table), which means the sample comes from a population that is normally distributed. While the normality test of the pretest value for the control class obtained the value of $\mathrm{L}_{-}$(count) $=0.111$, while L_(table) at the level of $\mathrm{a}=0.05$ and $\mathrm{n}=29$ is 0.161 . This shows L_(count) $<\overline{\mathrm{L}}$ (table), which means the sample comes from a population that is normally distributed. After calculation, the experimental class obtained the value L_ (count) $=0.141$, while L_(table) at the level of $a=0.05$ and $n=29$ is 0.161 . This shows L_(count) $<$ Ltable means the sample comes from a population that is normally distributed. While the normality test of the pretest value for the control class is obtained the value $L_{-}$(count) $=0.126$, while Ltable at the level $a=0.05$ and $n=29$ is 0.161 . This shows L_(count) < L table means the sample comes from a population that is normally distributed. Based on the normality test of the two classes, it can be concluded that the entire population of research data is normally distributed.

Based on the results of the testing phase of the development of fantasy makeup learning media products, it can be concluded that the developed fantasy makeup learning media is suitable for use in fantasy makeup learning in the field state cosmetology education study program and the first research hypothesis statement is the media for makeup learning instructional dictate character worthy of being used in fantasy makeup learning students in field state cosmetology education study program. And prove that hypothesis I is accepted.

Table 7 shows the total percentage score of the average trial hypothesis I

\begin{tabular}{llll}
\hline No. & Respondents Percentage & Percentage & Criteria \\
\hline 1. & Expert Learning Materials & $93.75 \%$ & Very Good \\
2. & Learning Design Expert & $80.08 \%$ & Good \\
3. & Learning Instructional dictate Expert & $89.99 \%$ & Very Good \\
4. & Individual Trial 88.32\% Very Good & $88.32 \%$ & Very Good \\
5. & Trial Small Group & $87.63 \%$ & Very Good \\
6. & Field Trial & $98.30 \%$ & Very Good \\
\hline Average & $89.67 \%$ & Very Good \\
\hline
\end{tabular}


Hypothesis II testing is done by the experimental method Normality test is made to look for normality of the sample under study. The normality test uses the Liliefors test. After the discussion, the experimental class obtained a value of $L_{-}$(count) $=0.136$, while Ltabel at the level of $a=0.05$ and $\mathrm{n}=29$ was 0.161 . This shows $\mathrm{L}_{-}$(count) $<\mathrm{L}_{-}$(table), which means the sample comes from a population that is normally distributed. While the normality test of the pretest value for the control class obtained the value of $L_{-}$(count) $=0.111$, while $L_{-}$(table) at the level of $a=0.05$ and $n=29$ is 0.161 . This shows $L_{-}$(count) $<L_{-}$(table), which means the sample comes from a population that is normally distributed.

After calculation, the experimental class obtained the value $\mathrm{L}_{-}$(count) $=0.141$, while $\mathrm{L}_{-}$ (table) at the level of $\mathrm{a}=0.05$ and $\mathrm{n}=29$ is 0.161 . This shows $\mathrm{L}_{-}$(count) $<\mathrm{L}$ tabel means the sample comes from a population that is normally distributed. While the normality test of the pretest value for the control class obtained the value $L_{-}$(count) $=0.126$, while the $L_{-}$tabel at the level of $a=0.05$ and $\mathrm{n}=29$ is 0.161 . This shows $\mathrm{L}_{-}$(count) $<\mathrm{L}_{-}$tabel means the sample comes from a population that is normally distributed. Based on the normality test of the two classes, it can be concluded that the entire population of research data is normally distributed.

Table 8 shows the total percentage score of the average hypothesis II that the hypothesis is accepted. Media Testing Information

Control Class Experiment Class

$80.46 \% 71.72 \%$ The hypothesis is accepted

\section{Conclusion}

Based on the formulation, objectives, results and discussion of research on the development of the fantasy makeup learning media presented earlier, it can be summarized as follows:

1. After going through several stages of testing, both the trial of material experts, the trial of learning design experts, and trials of instructional dictate and graphic design experts as well as trials for students, fantasy makeup instructional dictate learning products have results that are feasible to be the final product can be disseminated and implemented to users. This is made clear by the acquisition of an average rating of almost all stages, namely in the trial of material experts the overall average is $93.75 \%$ in the five-scale table, the value is categorized as "very good", in the trial of total learning design experts the overall average is $80.08 \%$ in the five-scale table, the value is included in the "Good" category, in the trials of the total instructional dictate experts and graphic design the overall average is $89.99 \%$ in the five-scale table, the value includes the category "Very good", in the total one-on-one trial the overall average was $88.32 \%$ in the fivescale table, the value included in the "very good" category, in the total small group trial the overall average was $87.63 \%$ in a scale five table, the value is in the category of "very good", in the total field trial the overall average is $98.30 \%$ in the scale table of five, the value includes the category "very good".

2. To see the effectiveness of the product, an analysis of student learning outcomes is carried out. Based on the analysis of 58 students participating in a large group the results of the use of fantasy makeup learning instructional dictate on student learning outcomes tests shows that the learning 
outcomes of students who are taught by using fantasy makeup learning instructional dictate are more effective $=12.06$. From the student learning outcomes taught using textbook learning media $=10.76$. Thus it was concluded that the learning outcomes of students taught using fantasy makeup learning instructional dictate were more effective than with student learning outcomes learned with textbook learning media, where data obtained from the results of fantasy makeup learning instructional dictate had an effectiveness of $80.46 \%$ higher than the effectiveness of textbook learning media is $71.72 \%$.

Based on the findings described in the conclusions and implications of the results of the research, the following are some suggestions, namely:

1. During this time the teaching and learning process carried out in practical subjects generally still uses printed media learning materials, so that learning refraction often occurs. This results in not achieving the ability to capture and apply the knowledge obtained.

2. Media fantasy makeup learning instructional dictate on fantasy makeup courses require adequate practice room facilities, so that when the lecture takes place it does not have to be bumpy to be able to do learning activities together which will be more efficient in using study time and having a long enough time.

3. The media for fantasy makeup learning instructional dictate is only a tool to assist in the process of delivering learning, therefore the existence of lecturers is still very much needed as a facilitator and students remain actively involved in the learning process of fantasy makeup courses.

4. In fact, until now the learning process of fantasy makeup courses is still done conventionally using textbook learning media. So it is recommended that the media for fantasy makeup learning instructional dictate can begin to be applied because the media for fantasy makeup learning instructional dictate are able to provide feedback better for students.

5. With limited time and costs, so that there are still some effects that have not been controlled, thus further research can be carried out in a more representative sample. 


\section{References}

[1] Smaldino, S.E, et al. Instructional Technology and Media For Learning, Jakarta: Kencana. (2008)

[2] Borg, W.R \& M.D. Gall. Educational Research: An Introduction, New York: Longman, Inc. (1983)

[3] AECT. Defenition and Terminology Committee Document \# MM4.0 June 1, 2004 [online] Available: http://www.indiana.edu/-molpage,/meanings\%200f\%20ET4.0.pdf, accessed on March 10, 2016. (2004)

[4] Anderson, Lw and Kaithwold. Framework for Learning, Teaching and Assessment, Jakarta: Learning Library. (1976)

[5] Arsyad, Azhar. Learning Media, Jakarta: Raja Grafindo Persada. (2002)

[6] Dick, W, Carey, L \& Carey, O. Systematic Design of Instructional (5th ed). New York: Addison-Wesley Educational Publisher Educational Technology Publicational, Inc. (2005)

[7] Gagne, E.D. The Cognitive Psychology of School Learning, Boston, Totonto: Little, Brown and Company Light, G. (1983)

[8] Gagne, Robert M. The Conditioning Of Learning. (Third ed). New York: Holt Rinehart and Wistnone. (1985)

[9] Gagne, Robert M, \& Briggs, Lessie J. Principle of Instructional Design, New York: Holt, Rinehart an Winston. (1979)

[10] Gerlach Vernon. S, Elly Donald.P. Teaching \& Media a Systematic Approach, New Jersey: Prentice Hall. (1980)

[11] Hamalik, Oemar. Media Pendidikan, Bandung: Citra Aditya Bakti. (2005)

[12] Kustanti, Herni et al., Skin Beauty Design of the Directorate of Vocational Development. Jakarta: Ministry of National Education. (2008)

[13] Kemp, J.E, G.R Morrison, and S.M. Ross. Designing effective Instruction, New York: Macmillan Collage Publishing Company. (1994)

[14] Miarso, Yusufhadi. Sowing Seeds of Educational Technology, Jakarta: Prenada Media and Pustekkon Diknas. (2004)

[15] Romizowski, AJ. Design Instrutional System: Decicion Making in Course. (1981)

[16] Sanjaya, Vienna. Learning Communication Media, Jakarta: Kencana Prenada Media Group. (2012)

[17] Saputra. Application of Learning Instructional dictate Tutorial Accounting Subjects In High School General Journal, Thesis: Educational Technology Study Program. Graduate program. Medan State University. (2011) 